\title{
Procedure and Design of a Patrimonial Tourist Product for the Municipality of "Calixto García"
}

\author{
Lisbet Eunice Pérez Anzardo ${ }^{1}$, Norton Peña Aguilera ${ }^{1}$, Roberto Eusebio Rodríguez Cedeño ${ }^{1}$, \\ Elizabet Yanet Pérez Hill ${ }^{1}$, Jessica de los Milagros Vela Batista ${ }^{1}$, Gustavo José Diaz García ${ }^{1}$, \\ Junier Reyes Tejeda ${ }^{1}$
}

Teaching Department of the Municipal University Branch Calixto García, University of Holguín, Holguín, Cuba

\section{Email address:}

lepereza@uho.edu.cu(L. E. P. Anzardo),npena@uho.edu.cu(N. P. Aguilera), rrodriguezc@uho.edu.cu (R. E. R. Cedeño), eperezh@uho.edu.cu (E. Y. P. Hill),jvelab@uho.edu.cu (J. de los M. V. Batista),gdiazg@uho.edu.cu (G. J. D. García), junier152@nauta.cu(J.R. Tejeda)

\section{To cite this article:}

Lisbet Eunice Pérez Anzardo, Norton Peña Aguilera, Roberto Eusebio Rodríguez Cedeño, Elizabet Yanet Pérez Hill, Jessica de los Milagros Vela Batista, Gustavo José Diaz García, Junier Reyes Tejeda. Procedure and Design of a Patrimonial Tourist Product for the Municipality of "Calixto García”. International Journal of Hospitality \& Tourism Management. Vol. 4, No. 1, 2020, pp. 1-7. doi: 10.11648/j.ijhtm.20200401.11

Received: July 15, 2019; Accepted: October 8, 2019; Published: February 28, 2020

\begin{abstract}
Tourism has constituted one of the sectors of more impact in the Cuban economy and in the last times the offers of this type have been diversified, favoring the products related with the nature and the culture of the communities. The municipality of Calixto García is located in the western part of Holguín province, framed around the central highway and its main economic line constitutes the agricultural sector. It also has significant natural, cultural and historical resources, but their management, in the search of transforming them into products of tourist attraction has been not enough to favor a sustainable and prospective development of the municipality, due to that an efficient use of the existent patrimonial resources is made. The present work proposes a patrimonial tourist product, related with the traditions of the local popular culture, incentivizing the protection of the natural diversity and the heritage. The potentialities of the municipality in this field are also exposed, as well as the particularities and the design of the product.
\end{abstract}

Keywords: Tourist Product, Patrimony, Tourist Attraction

\section{Introduction}

Tourism constitutes one of the social economic phenomena of more importance and quicker growth at world level. The modality of tourism of sun and beach has been, and it continues being, the market segment with the biggest contribution to the movements of international tourists scale. However, it is distinguished from the alternative tourism associated with the interaction, the experiences, the satisfaction and the personal enrichment.

The continuous growth of this sector has caused a bigger request in tourist products and the movement of these toward alternative forms, where the social responsibility for the protection of the natural is prioritized with more clarity, such as the historic and cultural values of the destination. An opportunity to take advantage is that the current tourist markets match with the main originators of nature tourism at international level; which demands the design of a tourist offer adapted to the new exchange necessities with the environment and the local cultures.

The electronic data base SciVerse Scopus was consulted with the aim of identifying research on tourism. [1] The analysis presented indicated that those related with agriculture, earth and planet represent just the $9 \%$ of the articles in this field. No articles on the sustainability in tourism was included. [2-6]

The traditional product of sun and beach, completed with the city, nature, historical and cultural tourism, as well as the most diverse forms, can be one of the most attractive destinations in Cuba where it is diversified with the necessary potential, starting with the design of exclusive tourist products, incentivizing and strengthening the tourism so that it continues being the motor of more impact in the 
Cuban economy.

The tourist destination of Holguín has wide development possibilities as a market-offer product. A territorial analysis would allow detecting its problem and its potentialities, that is to say, its conditions, weaknesses, strengths and the opportunities the natural and built by the man undeveloped resources offer. They should constitute an instrument for a municipal perspective planning, besides, they can aim for harmony in the middle of environmental protection; development of the community and the tourist's satisfaction.

Holguín has a high degree of tourist development, fundamentally in the seaside municipalities, but the recognition of the agricultural and cultural-traditional activity of the rest of the territory is limited, there is not an strategy in function for a real and objective tourist product with possibilities of being developed in sustainable way, which can contribute significantly to the recovery of the economy of the country and saving of our genuine culture.

The municipality of Calixto García is not exempt of it and it becomes necessary to design offers that encourage the national and international tourism; considering glands cape, fauna, floral, agricultural, historical and cultural ones. However, part of the representatives of the municipality lack knowledge and conceptualization of the modalities of alternative tourism. Besides, does not exist the infrastructures and necessary equipment for this modality of tourism and they lack a strategies for the creation and the positioning of the tourist products in the market.

\section{Main Results}

\subsection{Tourism Brief Conceptualization}

Tourism, in its more frequent definition, corresponds to a group of relationships and arisen phenomena of trips and people's temporary permanencies that move from its residence place and work, to places where they can develop diverse activities linked to rest and the recreation. The sustainable tourism can be defined as a process that allows that development takes place without degrading or draining the resources that facilitate that development.

Sustainability in tourism is defined as 'echo-tourism', 'green-tourism', or ' responsible tourism'. Whichever its description is, it is considered as a mean of recognizing that the earth possesses limited resources and that tourism, like in other sectors, has limits for the development mainly in specific places.

With the purpose of promoting the tourism and to create a responsible conscience when developing it, the General Assembly of the Organization of United Nations (UN) declared at 2017 as the International Year of the Sustainable Tourism for the Development. In the resolution adopted for the assignment of the year, the States members recognized the role of the international tourism for the progress and they underlined the necessity of understanding the worth of the heritage of the different civilizations and the inherent values of Culture to contribute to the peace of the world.

Connected to this interest of preserving our heritage, Cuba continues working for the acquired commitments with the $\mathrm{UN}$ in the context of the Calendar 2030 and the Objectives of Sustainable Development. Cuba, as a destination, will remain offering a sustainable tourist product, based on the principles of hospitality, peace and security that have motivated so many visitors.

Tourist product and its characteristics, the combinations of the resources and the services and equipment give place to the emergence of the tourist products; they satisfy the motivations and expectations of certain market segments. A new definition of tourist product is that it is the group of goods (tangible and intangible) consumed by a tourist in an area or certain geographical area for the satisfaction of the necessities that motivated them, the trip and those that arose during it [7]. A tourist product can be tangible because it can be a very physical or real allowing to be played or captured through the senses, it lasts in the time and it supports the benefit that lends, directly or intangible because it cannot be perceived by the senses, it is difficult to understand or to capture it and it wastes away in the moment that is manufactured. In another consulted bibliography [8] it is also defined as components of the tourist product the following ones: 1. Tourist attractiveness: All places, objects or event of tourist interest (OAS, 1978). These can be natural or cultural. 2. Tourist services: All the services that the tourist requires and he consumes while it is on trip. 3. Infrastructure: It is the endowment of goods and basic services which a country has and it allows a comfortable and pleasant trip, like transportation, basic services, and means of communications, among others. 4. Local community (the inhabitants, customs and traditions): The tourist product should include the residents, since they are the main difference between a place and another. 5. Perception - Image - Emotion (Sensation): Besides the characteristics that possesses a concrete destination, not all the tourists that visit will perceive equally its forms, since each one will shape his own image of the destination and will connect it with an emotion that finally transforms in sensations.

Tourist products, as the rest of the products, experience a cycle of life, since they reach the market until they are retired, passing by a series of stages: introduction, growth, maturity and decline.

The tourism is, without a doubt, one of the activities that contributes better to visualize the economic dimension of the heritage and to wake up certain concern for its conservation. Heritage has dimensions or diverse, cultural, social, symbolic or tourist functions. The concept patrimonial tourism constitutes a binomial that helps to fix position on a way of understanding the social use of the goods. This type of tourism is based and it promotes the knowledge, the exploration and the promotion of the heritage like social construction helping its preservation and putting the emphasis in the "alive culture" of the territories. 


\subsection{Design and Methodology for a Patrimonial Tourist Product}

For the sake of making a procedure in agreement to the demands of a rural community with agricultural characteristics and with an important historical and cultural tradition, several methodologies were consulted and a procedure was intended, taking as base the one published in September of 2011 [9] by Semassa Pierre Avoce, from Cotonú, Benín; which has as novelty the terminology: Management of the Commercialization of the product; modifying it and incorporating new indispensable elements in the stages developed in each one of the described phases.

Phase I: Diagnosis of the tourist situation

This phase includes four fundamental stages: 1 . Inventory of resources and tourist attractiveness. 2. Analysis of the demand. 3. Analysis of the competition. 4. Strategic analysis.

Phase II: Design of the product

1. Structuring of the product 2. Benefits of the tourist product. 3. Economic evaluation of the tourist product.

Phase III: Commercialization of the tourist product

1. Positioning, promotion and distribution channels. 2 . Feedback.

\section{Proposition of a Patrimonial Tourist Product for the Municipality of Calixto García}

\subsection{The Municipality of Calixto García}

Calixto García is the westernmost territory in Holguín province end it is among the ten municipalities of the country with bigger proportion of white skin population, with $89,2 \%$ of the total of inhabitants, but it is the second in the country with the lowest educational level and it is the biggest in aging population in the province. The territory is flat in the $73 \%$, with fertile savannas where the agriculture and the cattle raising is developed, which represents the $78 \%$ approximately of the commercial production of the territory. It produces $11 \%$ of the volume of viands of the county and it is the biggest milk producer at provincial level. The local culture is very bound to the rural life, the decimal poetry and the music of the oriental organ. Among its cultural contests stands out: The "Festival of Organs Pepe Ajo" and the Rural Festivities of Las Mantecas, both with potentialities to be inserted in the cultural tourism. [10-12]

\subsection{Identification of the Existent Tourist Potentialities in the Territory}

To be able to certify that a territory possesses a potential of tourist development that justifies certain investments in this sense, it is truly necessary to carry out a diagnosis of the existent capacities as the economic and historicalcultural activities of the place. The natural and cultural resources have as essential function to form part of the heritage and the collective wealth of the country, constituting the key elements of the national and local identity. These resources are the base of tourism and they should be valorized by means of the social appropriation since their conservation depends mainly of the importance the community assigns them. [13] The tourist potentialities are located fundamentally in: i) Flora and Fauna: In the municipality exists the equine genetic center "El libertador". it has six properties dedicated to the horse reproduction. It raises and develops about 700 animals and it has reached prizes in International Fairs. The application of the artificial insemination also assures the development of improved races of horses, used in the horsemanship and the agricultural works of the municipality. ii) Horseback riding: There is a special area for the practice of this discipline and gold and they have reached several gold medals in national and international contests. iii) Rodeo: It has been the equestrian entertainment that summons the biggest quantity of peoplein the territory. A Mexican, named Porfirio Manzano introduced this sport manifestation in 1970 with the creation of the first school of rodeo of the oriental region. Every year more than $50 \%$ of the members of the province team selected to contest in national events are from this territory, some of them with outstanding performances inside and outside the nation. [10-12]. iv) The organ of the Hermanos Ajos: On August $29^{\text {th }}$, 2016, the oriental organ was declared Cultural Heritage of the Cuban Nation. The Organ of the Hermanos Ajos is one of the oldest conserved in Cuba and it constituted the first cultural manifestation that the inhabitants of this territory know. Every year it is carried out the Festival of Organs Pepe Ajo in the municipality with the participation of organs of all the oriental provinces. A replica of the instrument it is distributed in the municipality as cultural symbol of the territory. [14]. v) History: The biggest relics in the historical-cultural heritage of the municipality of Calixto García come from the War of 1868, besides in 1956 it was constituted in the town of Mir the first cell of the "Movimiento 26 de Julio" and in October of 1958 the IV war front "Simón Bolivar" was organized. Two of its more important actions were the storming of a communication repetition center in the hill of Las Mantecas and the assault to the barracks of Buenaventura on December 31, 1958. [12]. vi) Religion and spiritism: Thera are 34 spiritual "cordoneros" centers. They are integral part of the culture of the municipality, and can be defined as intangible heritage. Spiritism has been practiced for more than a hundred years and for a great part of the population. There are also temples of the Catholic Church, Methodist, Pentecostal, Orthodox Church of God, Seventh Day Adventists and Witness of Jehová, which are diffused for almost the whole territory. [10-12]. vii) Craftmanship: Among its more significant productions are the wickerwork for furniture, boxes for buffet, marks for blinds, handbags, wallets, and candles. They use yarey, the leaf of the banana, plaster, wood and wax as material productions. viii) Dancing: Elegance's Dances mobilized all people and Mexican corrido and the Caringa Calixteña are traditional 
dances, besides the Son, accompanied most of the times with the organ music. ix) Calixteña Literature: Consuelo Álvarez Valdés was the first holguinean female novelist at the beginning of the last century; she was also a teacher in a rebel prefecture. The poet Emilio Ballagas Cubeñas visited and stayed in Buenaventura town for a while. At the present time the municipality has good writers, poets and composers. $\mathrm{x}$ ) Cock fights: Many people sustain that this is the Cuban province with the best tradition in cock fights, and every March takes place a territorial tournament. xi) Sport: Baseball is an appendix of its history, customs and traditions. The famous team of the town is named the "Western Cowboys" and won a national tournament in 1996 , which is a historical event. Soccer is also very popular. xii) Local food: The typical Cuban food is influenced mainly by the Africans and the Spaniards, from them arose the Creole flavor. The most authentic are: roasted pig in spike, casaba root, stewed meat, congris rice, tamales, pottage, ajiaco and others. Rum represents Cuban roots. Other drinks but without alcohol are the guarapo (sugar cane juice), pru and the champola. Coffee is exquisite. The candies characteristic of the area are the fruits in syrup, coconuts, peanut candies, the guava marmalade with cheese, the boniatillo, the coconut candies and the traditional raspadura with yagua cover.

\subsection{Design of the Patrimonial Tourist Product Andits Insertion in Holguín Tourist Destination}

Patrimonial tourism is a different way to enjoy the customs andrural areas of the country, which gets the attention to be closely linked to the nature.

Phase I: Diagnosis of the tourist situation

1. Inventory of resources and tourist attractiveness.

Using surveys, interviews and taking into account the diagnosis of the existent capacities in the municipality, we could identified that the local tourist attractiveness can be an impeller motor for the approach of clients to our town since it is had a great variety of urban, natural and rural resources where the traditional and patrimonial values are reflected, guaranteeing a sustainable use of them.

2. Analysis of the demand.

In 2015, according to data of the World Organization of the Tourism (OMT), in the entire world there were near to 1.200 million international tourists' arrivals, which is practically equal to the seventh part of the population's world. In 2019 Cuba calculated to overcome the 5 million foreign visitors. It is considered that it would mark a new record after of those almost 4, 7 and 4, 5 millions foreign visitors that were in the island in 2017 and 2016, respectively.

The Holguíndestination received in 2017 more than 200 thousand foreign visitors. It represents 12 percent more than that of the same period of the previous year. It demonstrates a growing acceptance of this journey's end, with no only potentialities in the modality of sun and beach, but also nature, risks and city tourism. Holguín has more than five thousand rooms, distributed fundamentally in four or five stars hotels, located in Pesquero beach, Esmeralda beach, and Guardalavaca beach, where the hotel Albatros of the corporation Iberostar is built.

Every week arrive about 80 flights of 20 air companies, fundamentally from Canada, England and Germany, and some regular commercial flights from United States. It has a top increasing in the months of July and August in the case of the national ones and starting from September in the case of the foreigners. Holguín is the third tourist pole of Cuba, so this project is designed mainly for the national and foreigners tourists that daily go by the central highway and they do not have a service or a tourist product in a distance of $80 \mathrm{Km}$., from the city of Las Tunas to Holguín. Daily for the municipality pass more than 100 tourists approximately who do not contribute economically in a direct way, due to that there is not an endogenous, cultural product of national interest in this highway tract.

\subsection{Analysis of the Competition}

There are different forms of alternative tourism mainly in the coastal areas in Holguín, but in the municipality object study does not exist any entity that offers recreational and cultural activities combined with spaces dedicated to the exchange with the nature and the traditions of the community. Some companies that manufacture products for the commercialization in foreign currencies exist, but isolated, so there is not rivalry for the tourist product which is proposed. [15]

\subsubsection{Strategic Analysis}

The strategic analysis is made to project with a clear business vision and to define the main goals and action lines. The DAFO mold is carried out based on the objective of the project, which allows us to obtain a clear diagnosis for best decisions making, keeping in mind the strengths, opportunities, weaknesses and threatens.

\section{$D A F O$}

To carry out the DAFO mold an internal analysis of the project it was made considering the strengths and weaknesses and then an external analysis reflecting the threats and opportunities of the environment.

\section{Internal analysis}

Strengths:

Strategic geographical situation of the municipality.

Resources and historical, cultural, natural and agricultural attractiveness not very exploited for the implementation in the different ways of tourism.

Wide experience in agricultural competitions, sport and recreation.

Local festival of organs.

Necessity to increase tourism for the local development.

Necessity to improve the internal articulation of tourist flow that moves for the central highway.

Weaknesses:

Insufficient use by town management of tourist potential and of human, natural and cultural heritage to transform them into products. 
Lack of appropriate infrastructure for the reception of tourists.

Scarce utility of the central highway and the railroad as roads of access and mean of transportation since a tourist point of view.

Little connection and exchange among nearer cities.

Defective professional formation in the sector of the tourism.

Insufficient rural identity.

External analysis

Opportunities:

The new tendencies of tourists, in the demand of an alternative and patrimonial tourism.

Possibility to compete in the tourist sector with a nonmassive quality product.

Growing tendency toward the active tourism of experiences and more genuine and less artificial emotions.

High affluence of foreign tourists to the country, as well as an avid internal tourism of discovering its own country.

Politics of local development.

Use of the net of roads for tourist use (hiking, equestrian routes, agricultural routes, etc.)

Revaluation of the cultural and traditional heritage.

Threats:

Environmental deterioration.

Increase of other similar tourist destinations.

Internal tourism with desires and emotions to discover their own country.

Economic embargo.

\subsubsection{Strategies to favor the Strengths}

It was defined the following strategies to favor the strengths, to overcome the weaknesses, to control the threats and to benefit of the opportunities:

To satisfy with the proposal of a patrimonial tourist product, the demand of the national and international market, incorporating the natural, historical and cultural resources of the municipality.

To create the necessary infrastructure for the attention to the tourists, as recovering and restoring the roads of the territory for a sustainable tourism.

To strengthen the relationships with the travel agencies and tourist representative who operates in Holguin to improve the distribution process and communication of the designed product.

To integrate the services that can be offered to the national and foreigner tourism, achieving a bigger quality and image in the potential markets.

To qualify the personnel in the sectors linked to the tourist activity to achieve the identification with the values and the traditions of the community, offering a distinctive service to the client.

To signal in the central highway the different points where tourist offers will be located, based on the cultural, gastronomical appeal and traditional services, organizing the space in function of the cultural and environmental heritage.

To promote the patrimonial tourist product using the different means of massive diffusion, as well as a catalog of products that can be offered to the national and foreign tourist, where the most excellent cultural and historical aspects in each place will be explained.

To sell handmade products, curiosities or souvenirs of the agricultural process.

To offer tastings of foods and food sales prepared with products cultivated in the municipality, as well as dry desserts and canned food based in fruits, honey, etc.

To minimizes the negative impacts on the natural and sociocultural environment.

To give active participation to the local government and other directives of the municipality in function of positioning the designed product.

\subsection{Phase II: Design of the Patrimonial Tourist Product}

\subsubsection{Structuring of the Product}

The proposal of the tourist product, takes for name: "Tour of Agricultural Diversity in Calixto García". The tourist will be able to share a magic day in a tour that has the active or passive participation with the inhabitants that carry out agricultural, commercial and services works in the town. In this rural tourism adventure, the client will be accompanied by experts that will tell him the secrets of the community and it includes: A big cottage where they can taste traditional dishes, a coffee, other drinks and gastronomic offers. A place where our flora and fauna can be exhibited, horse ridings in a beautiful environment, a farming cooperative visit, as well as the farm of the best cattleman in the municipality where they can know the experience on the internal handling of the agriculture, focused in sustainable development. It can also include the planting of a tree that it is registered by them in the place and itinerary, so they can return with the intention of knowing on its growing and treatment.

They can also visits the cultural center of the municipality, where they can enjoy a good rodeo show, a horsemanship show, a cock fight, as well as sport activities. They can also acquire handmade products, books; take part in auctions, exhibitions, etc., so they can be acquainted with a cultural presentation in the culture center with typical dances, with the performance of the organ "Hermanos Ajos"; and the sale of souvenirs. Later, they can go to the museum, to have an approach of the history of the community by means of a vivid representation of some historical events.

It includes: Transportation, lunch and local guide.

It is recommended: Comfortable shoes, cap or hat, camera. Duration: 8 hours approximately with a weekly frequency. Minimum: 25 pax

Price: \$ 10.00 cuc

\subsubsection{Benefits of the Tourist Product}

The incorporation of tourist activity to the rural sector has aroused great interest because it assists a growing demand. It occupies lazy factors (manpower and capital), and it avoids the exodus of people from the field, incorporating the woman and youths as main characters. It is looked for that the activity represents an alternative to achieve the rural 
population to benefit with the participation of its economic activity by means of the agriculture and the tourism. Among the benefits of this practice are the symbolic ones since this activity responds to emotions perceived by exclusive services and for the guide of excellent characters inside the municipality. They also put on in function the human being senses being able to accumulate experiences outdoors and in direct contact with environment without damaging it, also impelling to the community to achieve a sustainable development. One can also add that it is innovative, associative, ecological, educational and social. [13]

\subsubsection{Economic Evaluation of the Tourist Product}

To obtain the total amount of the investments it was kept in mind the data consulted with specialists of the Real State for the Tourism in Holguín during the implementation of tourist products in other towns of the province. [16]

Table 1. Budget for equipment and infrastructure of the tourism product

\begin{tabular}{llll}
\hline Activities & Budget in hard currency & Budget in Cuban pesos & Total \\
\hline Construction and Assembly & $\$ 51800.00$ & $\$ 10000.00$ & $\$ 61800.00$ \\
Equipping & 20000.00 & 15000.00 & 35000.00 \\
Other costs. & 17500.00 & 23700.00 & 41200.00 \\
Total & $\$ 89300.00$ & $\$ 48700.00$ & $\$ 138000.00$ \\
\hline
\end{tabular}

According to studies carried out with relationship to the affluence of tourists to Holguín and the arrivals to the oriental area by means of the Agency of trips "Viazul", once the product is on service around 50 daily tourists will assist, besides the national tourism that also generate incomes for this concept. To calculate the recovering time for the investment in total currency starting from the price fixed for international tourism it was carried out the following calculation, knowing that:

1. Total amount of the investment $\mathrm{I}=\$ 138000.00$ Total Currency.

2. Sale price $\mathrm{p}=10.00 \mathrm{CUC}$.

3. Level of use annual $u 1=18250$ ( 50 clients $\times 365$ days)

4. Total of annual incomes Ip1 $=\$ 182500.00$ (50 clients $\mathrm{x}$ 365 days $x \$ 10.00$ )

5. Annual fixed cost $\mathrm{F}=15000$ (estimated value)

6. Unitary variable cost $\mathrm{v}=1.52$ (estimated value)

"Period of Return of the Investment PRI=I/(p.u-(F+v.u))

PRI $=138000 /(10 ? 18250-(15000+1,52.18250))=0.987$

It means that approximately in three months and ten days a movement of enough funds will be generated to recover the investment.

Internal yield rate (TIR).

In this case the TIR $=(\mathrm{Ip} / \mathrm{I})-1=(182500,00 / 138000)-1=0,32$ represent a gain of $32 \%$ above the investment.

Net Current value (they GO).

$$
V A N=\frac{V_{F} t}{(1+T I R)^{t}}-I_{O}=0
$$

For this project in matter

$\mathrm{VAN}=(182500 / 1+0,32)-138000=257,57$ as the result the bigger or the same aszero is accepted the project.

\subsection{Phase III: Administration of the Commercialization of the Product}

\subsubsection{Positioning, Promotion and Distribution Channels}

The promotion and commercialization of this project is fundamental, since it will be inserted in an existent market through a group of strategies keeping in mind the objectives that are pursued; accentuating the patrimonial, historical and agricultural values of the municipality to highlight its place in the holguinean destination, for the sake of differentiating it from other products that the clients can find in other towns. It was considered that the first communication effort will be to offer an excellent attention to the client to transform it into its main communicator, besides the use of the means of comunicatios, among others. It is considered appropriate to carry out an advertising campaign through Internet, to include the product in guides, posters, pamphlets and catalog of the destination where it is explained about the Cuban rural culture in general and that of the community in particular, etc.

\subsubsection{Feedback}

All projects undertaken require of supervision and control, that is to say, feedback the design of the product with the vision of the clients. The BCG mold or the Mold of growth participation is a tool that consists on carrying out a strategic analysis of the briefcase of the company based on two factors, the rate of market growth and the market participation. Its purposes to help in the taking of decisions on the different focuses and it tell us what companies or areas should invest or end the business.

\section{Conclusions}

1. Patrimonial tourism constitutes a modality based on the knowledge, the exploration and promotion of the heritage as social construction, to help to its preservation and development, putting emphasis in the alive culture of the territories, allowing the tourist to know deeply the customs and the population's traditions.

2. The design of tourist products based on the natural attractiveness constitutes an opportunity to diversify the offer of any destination, whenever they respond to the current demands and be able to contribute a unique and unforgettable experience.

3. A diagnosis of the possible attractiveness and of the environment of the municipality was carried out, verifying that the tourist activity it is not exploded and that this can generate utilities and to get a sustainable 
local development.

4. With the analysis of the economic feasibility it can be predicted that the product is economically viable and sustainable, and that with the utilities that are acquired it can incentivize the development of the community and the growth of this project.

5. The municipality has an advantageous geographical position for the development of this modality and it is also an eminently agricultural area, and together with the growing demand of an alternative tourism and the low competition could transform it into a tourist potential in the territory.

6. The impulse of this modality and the development of tourist products can become a contribution to the local development where the communities and the small and medium venturesome businessmen play the leading role. It can also contribute to the recreation of its residents, to its intellectual growing and to elevate the family economy along with the municipality one; as well as to make an important contribution for Cuba.

\section{Recommendations}

1. To present the results from the investigation to the authorities of the Municipality of Calixto García and to the Delegation of the MINTUR looking for its implementation.

2. To design and to publish materials for the promotion of the patrimonial tourist product for the municipality of Calixto García with information about the attractiveness and benefits of the product; as well as to contact with travel agencies to create a link in their web pages promoting the product, images and information of the project.

3. To continue deepening in the topic of patrimonial tourism as alternative of diversification of the regional offer and option of development of the national rural communities, on the base of sustainable approaches.

\section{References}

[1] Electronic data base SciVerse Scopus, consulted September $15^{\text {th }}, 2019$.

[2] Agamirova, E. V., Lebedeva, O. Y., Lebedev, K. A., \& Ilkevich, S. V. (2017). Methodology of estimation of quality of tourist product. [Article]. Quality-Access to Success, 18 (157), 82-84.

[3] Albuquerque, H. C. D. C., Martins, F. M. C. P. F., Raposo, R. M. D. A., Cardoso, L. M. T. G., Beça Pereira, P. M. D. S., \&
Dias, P. (2016). Construction of a web-based geographical information system-the case of "Ria de Aveiro" region. [Article]. Anatolia, 27 (1), 71-81. doi: $10.1080 / 13032917.2015 .1083210$

[4] Aleksushin, G. V., Ivanova, N. V., \& Solomina, I. J. (2020) The use of technology of digital economy to create and promote innovative excursion products. Vol. 908. Advances in Intelligent Systems and Computing (pp. 404-410).

[5] Almakhadmah, I. M. (2019). The role of the tourist mix in activating christian religious tourism in Madaba Governorate, Jordan. [Article]. African Journal of Hospitality, Tourism and Leisure, 8 (3).

[6] Bachok, S., Amin, T. A. T. M., \& Rahman, S. A. A. (2018). In pursuit of economically competitive agro-Tourism sector: The case of terengganu homestay, Malaysia. [Article]. Planning Malaysia, 16 (2), 164-174.

[7] Pérez Campdesuñer, R. (2007). Modelo y procedimiento para la gestión de la calidad del destino turístico holguinero. Tesis presentada en opción al grado científico de Doctor en Ciencias Técnicas.

[8] Manual Paso a paso para el Diseño de Productos Turísticos integrados»Subdirección de Productos y Destinos Sustentables SERNATUR (2015)

[9] Pierre Avoce, S. (2007). Análisis de factibilidad económica del proceso inversionista en el parque turístico Rio Canimar, Trabajo de diploma de Licenciatura en Economía, Facultad de Industrial EconomíaUniversidad de Matanzas, (U.M.C.C).

[10] Calixto García (Holguín)-https://www.ecured.cu

[11] En Calixto García... la bienvenida, y el hasta pronto_web@radiorebelde.icrt.cu

[12] Tradiciones y ritos en Cuba, fuentes de nuestra identidad http://ww.radiojuvenil.icrt.cu36. Turismo en tierras de Holguín. http://www.cuba.travel/destinos/holguin/excursions-en-holguin

[13] Desarrollo de Productos Turísticos (2011) Temas en la Maestría en Gestión Turística, Universidad de Holguín, Centro de Estudios Turísticos.

[14] Fiesta al ritmo del son "molí’”" del Órgano de los Hermanos Ajo. http://www.ahora.cu

[15] Ávila Guilarte, Y. (2013) Análisis territorial de las instalaciones recreativas extrahoteleras en el sector turístico bahía de Vita-bahía de Samá, Holguín. Trabajo de diploma en opción al Título de Licenciado en Turismo, Universidad de Holguín.

[16] González Sainz, Y. (2012). Propuesta de diseño del producto turístico Centro Recreativo Cultural El Molino Rojo en Gibara, Trabajo de Diploma en opción al título de Licenciado en Turismo, Universidad de Holguín. 